\title{
Comparative Studies Between Mauritia flexuosa and Mauritiella armata
}

\author{
Vanessa de Andrade Royo ${ }^{1, *}$, Juliana Almeida Rocha ${ }^{1}$, Kamylla Teixeira Santos ${ }^{1}$, Jeane Ferreira Leal Freitas ${ }^{1}$, \\ Clarice Avelar Almeida', Bianca Ribeiro', Elytania Veiga Menezes², Dario Alves de Oliveira², \\ Murilo Malveira Brandão ${ }^{2}$, Afranio Farias de Melo Júnior ${ }^{2}$
}

\section{Vanessa de Andrade Royo ${ }^{1, *}$, Juliana Almeida Rocha ${ }^{\prime}$, Kamylla Teixeira Santos ${ }^{1}$, Jeane Ferreira Leal Freitas ${ }^{1}$, Clarice Avelar Almeida', Bianca Ribeiro', Elytania Veiga Menezes², Dario Alves de Oliveira², Murilo Malveira Brandão², Afranio Farias de Melo Júnior $^{2}$}

'Laboratory of Natural Products, State University of Montes Claros, Avenida Dr. Ruy Braga, S/N - Vila Mauriceia, 39401-089, Montes Claros - MG, BRAZIL. ${ }^{2}$ Laboratory of Bioporpection and Genetic Resources, State University of Montes Claros, Avenida Dr. Ruy Braga, S/N - Vila Mauriceia, 39401-089, Montes Claros - MG, BRAZIL.

\section{Correspondence}

Prof. Vanessa de Andrade Royo

Laboratory of Natural Products, State University of Montes Claros, Avenida Dr. Ruy Braga, S/N - Vila Mauriceia, 39401-089, Montes Claros - MG, BRAZIL.

Phone no : +55 3832298061

E-mail: vanroyo31@gmail.com

History

- Submission Date: 31-08-2018;

- Review completed: 13-09-2018;

- Accepted Date: 22-11-2018

DOI : 10.5530/pj.2019.1.6

Article Available online

http://www.phcogj.com/v11/i1

Copyright

(C) 2019 Phcog.Net. This is an openaccess article distributed under the terms of the Creative Commons Attribution 4.0 International license.

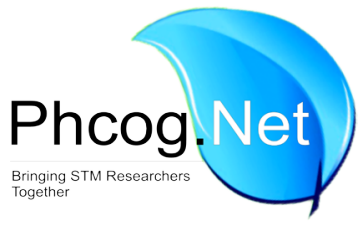

\section{ABSTRACT}

Mauritia flexuosa and Mauritiella armata belong to the family Arecaceae and are widely found in Brazil. Aim: In this work were evaluated: the phytochemical profile of the secretion popularly known as $M$. flexuosa wine, antioxidant activity of leaf, root and petiole hydroethanolic extracts of the two species, as well as the quantification of flavonoids and the chromatographic profile by means of High Performance Liquid Chromatography. Materials and Methods: The chromatographic profile was determined by high performance liquid chromatography, quantification of flavonoids and antioxidant activity, were performed by spectrophotometric method. Results: Antioxidant activity and presence of flavonoids were observed in the extracts of all the analyzed structures of the two species. The phytochemical profile of the wine evidenced the presence of secondary metabolites reported in other structures of M. flexuosa. In the chromatographic analysis, it was observed that the extracts evaluated have between three and nine compounds. Conclusion: Further studies should be performed to identify the active compounds in the two species.

Key words: Antioxidant activity, Arecaceae, Flavonoids, Phytochemical, Secondary metabolites. Key Messages: In this work were evaluated: the phytochemical profile of the secretion popularly known as $M$. flexuosa wine, antioxidant activity of leaf, root and petiole hydroethanolic extracts of the two species Mauritia flexuosa and Mauritiella armata (Arecaceae), as well as the quantification of flavonoids and the chromatographic profile.

\section{INTRODUCTION}

The Arecaceae family is composed of 1500 species distributed in 200 genera, found mainly in tropical areas of the planet. They are part of this family the Mauritiella armata (buritirana ou xiriri) ${ }^{1,2}$ and also the Mauritia flexuosa (buriti, miriti, muriti or palmeirado-brejo), ${ }^{3}$ this last secretes a substance called wine, which has easy fermentation and is used in folk medicine as a fortifier and in the control of intestinal problems. ${ }^{4,5}$

These palm trees have wide distribution in Brazil. ${ }^{6}$ The fruits of both are important sources of food for local fauna, ${ }^{7}$ from the pulp of the fruits of $M$. flexuosa are produced ice cream, jellies, oil, sweets and wine and due to the antioxidant potential, can be added for example in cosmetic formulations or for the study of new drugs by the ability of phenolic compounds of inactivation of reactive species, preventing excessive oxidation which can lead to structural changes in molecules of the organism causing inflammation, cardiovascular diseases, neurodegenerative diseases, atherosclerosis, among others., ${ }^{3,8-11}$

Faced with this, the objective of this work was to carry out phytochemical prospecting in the M. flexuosa wine, to investigate antioxidant activity, to quantify flavonoids and to verify the chromatographic profile by means of high efficiency liquid chromatography (HPLC) of hydroethanolic extracts of $M$. flexuosa (wine, petiole, leaf and root) and M. armata (leaf, petiole and root).

\section{MATERIALS AND METHODS}

\section{Collection of plant material}

Samples of petiole, leaf and root of three different individuals of M. flexuosa and M. armata were collected in region of vereda in Bonito of Minas Gerais, the collection was carried out by the Doctor Maria Olivia Mercadante Simões. The plant material was oven dried at $40^{\circ} \mathrm{C}( \pm 2)$ until it presents a constant mass, later it was pulverized and stored in paper bags in the refrigerator $\left(5^{\circ} \mathrm{C}\right)$. Exsicates were deposited in the Montes Claros Herbarium: MCMG and identified by Rubens Manoel dos Santos (Mauritia flexuosa Mart. (Buriti) n. 5777; Mauritiella armata (Mart.) Burret (Xiriri) n.5778a.

Cite this article: Royo VA, Rocha JA, Santos KT, Freitas JFL, Almeida CA, Ribeiro B, et al. Comparative Studies Between Mauritia flexuosa and Mauritiella armata. Pharmacog J. 2019;11(1):32-6. 


\section{Preparation of the extract}

For each $10 \mathrm{~g}$ of plant material $100 \mathrm{~mL}$ of $70 \%$ ethanol was added. The mixture was kept at controlled temperature at $35^{\circ} \mathrm{C}( \pm 2)$ for seven days, then filtered and placed in a greenhouse at $40^{\circ} \mathrm{C}( \pm 2)$ for three to five days for solvent drying, then they were stored in a refrigerator at $-5^{\circ} \mathrm{C}$ until the time of analysis.

\section{Phytochemical analysis}

It was evaluated the presence of secondary metabolites: glycosides, ${ }^{12}$ saponins, steroids and terpenes following the methodology of Royo et al. ${ }^{13}$ anthraquinones were identified according to Mello et al. ${ }^{14}$ and Falkenberg et al. ${ }^{15}$ Tests to verify the presence of alcohols were made as described by Andrade. ${ }^{16}$ The acidity, aldehyde and ketone tests were reproduced according to the procedures suggested by Cruz and Galhardo. ${ }^{17}$ The verification of reducing sugars was done using the methodology described by Beserra et al. ${ }^{18}$ and the thin layer chromatography (TLC) technique reported by Mercadante-Simões et al. ${ }^{19}$ with modifications.

\section{High Performance Liquid Chromatography (HPLC)}

Each extract was diluted in $0.1 \%$ trifluoroacetic acid solution: acetonitrile $(90: 10)$ at $1 \mathrm{mg} / \mathrm{mL}$ concentration, taken ultrasonic bath for $10 \mathrm{~min}$, then filtered on a millex filter and injected into the liquid chromatograph (Waters), equipped with binary pump 1525, automatic injector 717, automatic fraction collector III, diode arrangement detector 2996 and Soft Ware Empower 1, previously stabilized. The column used was type C18 250×4.6 mm 5 micron Spherisorb. The mobile phase used was a $0.1 \%$ trifluoroacetic acid solution diluted in acetonitrile (99:1). The injection volume of the samples was $20 \mu \mathrm{L}$, which ran in a flow of $0.6 \mathrm{~mL} / \mathrm{min}$. Readings of peak were taken at the wavelength of $220 \mathrm{~nm}$. The analyzes occurred at a temperature of $30^{\circ} \mathrm{C}$.

\section{Quantification of flavonoids}

The total flavonoid content was determined from the Alves and Kubota ${ }^{20}$ spectrophotometric method with the use of aluminum chloride. The standard curve equations were obtained from reading the absorbances at the $425 \mathrm{~nm}$ wavelength of the standard standard solution of rutin $(20,25.30,35,40,45 \mu \mathrm{g} / \mathrm{mL})$. In $100 \mu \mathrm{L}$ of $\mathrm{AlCl}_{3}$ methanolic solution $(5 \% \mathrm{w} / \mathrm{v})$, it was added $600 \mu \mathrm{L}$ of samples, at the concentrations of 100 , $200,300,400,500 \mu \mathrm{g} / \mathrm{mL}$ and the volume was completed to $2.5 \mathrm{~mL}$ with methanol.

\section{Antioxidant Activity}

The evaluation of the antioxidant activity of the samples was measured by the DPPH free radical sequestering method (2,2-Diphenyl1-1-Pricrilhydrazyl) described by Brand-Williams, ${ }^{21}$ with modifications. The stock solution of DPPH was prepared at the concentration of $40 \mu \mathrm{g} / \mathrm{mL}$ and stock solutions of the samples prepared at $500 \mu \mathrm{g} / \mathrm{mL} .^{21,22}$ Samples and DPPH were diluted in methanol.

In separate test tubes were pipetted $3 \mathrm{~mL}$ of DPPH and $0.5 \mathrm{~mL}$ of the solutions of each sample in the concentrations according to Table 1. Then the samples stayed for 30 min under cover the light and then was proceeded the spectrophotometer read at a wavelength of $517 \mathrm{~nm}$. For white, methanol was used and for the negative control it was pipetted $3 \mathrm{~mL}$ of DPPH and $0.5 \mathrm{~mL}$ of methanol. Gallic acid was used as a positive control at concentrations from 0.33 to $1.66 \mu \mathrm{g} / \mathrm{mL}$. All the tests were performed in triplicate and the mean of the results was used for the calculation of percentage of antioxidant activity.

The percentage of antioxidant activity (\% AA) was calculated with equation 1 :
$\% \mathrm{AA}=\left(\frac{\mathrm{AbsConst}-\mathrm{AbsAmos}}{\mathrm{AbsCont}}\right) \times 100$

Where AbsCont is the absorbance value of the control and AbsAmos represents the absorbance value of the sample. ${ }^{22}$

\section{RESULTS AND DISCUSSION}

\section{Phytochemical analysis of wine}

They were identified: Glycosides, anthraquinones and saponins in the most concentrated dilutions of wine and still steroids and triterpenoids in extraction I, but not in extraction II. The M. flexuosa also has these metabolites in other structures, for the ethanol extract from its leaves has already been reported presence of steroids / triterpenoids, saponins, flavonoids and tannins. ${ }^{23}$ In the pulp there are phenolic compounds, flavonoids and phytosteroids. ${ }^{24}$ And in the roots there are flavonoids and triterpenes ${ }^{25,26}$ (Table 2).

Aldehydes were not detected as well as reducing sugars in both TLC and Fehling reactions. However, it was detected the presence of ketones and alcohols in a most intense way in the potassium dichromate test than in ferric chloride, which is directed to identification of phenols. ${ }^{27}$ The verification of ketones, alcohols and the $\mathrm{pH}=4$ may be due to the fermentative process that consumed the sugars, where the primary alcohols produce acids and the secondary alcohols, the end product is the ketone. ${ }^{28,29}$

\section{Chromatographic analysis}

In the extracts of the two species, the compound with retention time from 6.545 to $6.574 \mathrm{~min}$ was the majority for all analyzed parts. The compound with retention time between 5.257 and $5.351 \mathrm{~min}$ was the second most found in all structures, except for the root of M. armata where the second most prevalent compound is the one with retention time from 4.231 to $4.227 \mathrm{~min}$, being this the third major in: leaves of both species and in the petiole of $M$. flexuosa (Table 3).

In the leaves of $M$. flexuosa were identified eight compounds, whereas this structure in $M$. armata has only three compounds, which coincide in prevalence in the two species. In the M. flexuosa root were detected six compounds and in $M$. armata seven. It is possible to verify that the compound with retention time 6.545 to $6.574 \mathrm{~min}$ is majority in the roots of both species and the compound with retention time 5.928 to 6.098 min is not present in the roots of $M$. flexuosa. The other compounds vary in quantity in the roots of the two plants. Among all the extracts the petiole of M. armata was the one with the highest number of compounds (9) (Table 3).

In M. flexuosa wine there are six compounds, the retention time of these substances was different from the retention times of the compounds found in the plant structures, as can be observed in Table 3.

\section{Antioxidant activity and quantification of flavonoids}

All the samples had antioxidant activity and it was possible to verify the presence of flavonoids, however when compared, the structures of M. armata showed higher antioxidant activity and amount of flavonoids than in the corresponding samples of $M$. flexuosa (Table 4).

In both palms, the leaf extracts were the ones with the highest $\mathrm{EC}_{50}$ value as can be seen in Table 4. In M. armata and M. flexuosa the leaves exhibited greater antioxidant potential and flavonoid content than the leaves of Calamus rotang $\left(\mathrm{EC}_{50}\right.$ of $387,948 \mu \mathrm{g} / \mathrm{mL}$ and flavonoid content of $2.68 \mathrm{EQ} \mathrm{mg} / \mathrm{g})^{30}$ which is popularly used as antihelmintic and in the treatment of eye problems. ${ }^{31}$ However, they have less antioxidant activity than the leaves of Phoenix dactylifera $\left(\mathrm{EC}_{50}\right.$ corresponding to 7.44 to 
Table 1: Sample concentrations in the antioxidant activity tests.

\begin{tabular}{ccc}
\hline Sample & Part of the plant & Concentrations \\
\hline \multirow{3}{*}{ M. flexuosa } & Root & $80,100,120,140,160 \mu \mathrm{g} / \mathrm{mL}$ \\
& Petiole & $100,200,300,400,500 \mu \mathrm{g} / \mathrm{mL}$ \\
& Leaf & $80,100,120,140,160 \mu \mathrm{g} / \mathrm{mL}$ \\
M. armata & Wine & $0.5 \%$ to $100 \%$ of its natural concentration \\
& Root & $20,40,60,80,100 \mu \mathrm{g} / \mathrm{mL}$ \\
& Petiole & $100,200,300,400,500 \mu \mathrm{g} / \mathrm{mL}$ \\
& Leaf & $120,140,160,180,200 \mu \mathrm{g} / \mathrm{mL}$ \\
\hline
\end{tabular}

Table 2: Phytochemical profile of wine.

\begin{tabular}{|c|c|c|c|c|c|c|c|c|c|c|c|}
\hline Test & Reaction & \multicolumn{10}{|c|}{ Result } \\
\hline \multirow[t]{2}{*}{ Steroides } & $\begin{array}{c}\text { Extraction I } \\
\text { (Bouchardart) }\end{array}$ & & & & & & r+ & & & & \\
\hline & Extraction II & & & & & & - & & & & \\
\hline Glycosides & $\begin{array}{l}\text { Ammonium } \\
\text { hydroxide }\end{array}$ & & & & & & + & & & & \\
\hline \multirow[t]{2}{*}{ Reducing sugar } & Fehling A e B & & & & & & - & & & & \\
\hline & TLC & & & & & & - & & & & \\
\hline \multirow[t]{2}{*}{ Anthraquinones } & Direct reaction & & & & & & & & & & \\
\hline & $\begin{array}{c}\text { Reaction with } \\
\text { previous acid } \\
\text { hydrolysis }\end{array}$ & & & & & & + & & & & \\
\hline \multirow[t]{2}{*}{ Alcohol } & $\begin{array}{l}\text { Potassium } \\
\text { dichromate }\end{array}$ & & & & & & & & & & \\
\hline & Ferric chloride & & & & & & + & & & & \\
\hline Aldehydes & Fehling & & & & & & & & & & \\
\hline Ketones & $\begin{array}{l}\text { Iodo from } \\
\text { testing }\end{array}$ & & & & & & + & & & & \\
\hline Acidity & - & & & & & & & & & & \\
\hline \multirow[t]{2}{*}{ Saponins } & Persistent foam & 1 & 2 & 3 & 4 & 5 & 6 & 7 & 8 & 9 & 10 \\
\hline & & - & - & - & - & - & - & - & + & + & + \\
\hline
\end{tabular}

(+) weak; (++) moderate; (+++) intense; (-) negative
$12.61 \mu \mathrm{g} / \mathrm{mL}),{ }^{32}$ parts of this plant are used in traditional medicine for the treatment of disorders of memory, fever, inflammation, paralysis and its leaves in particular possess antibacterial activity. ${ }^{33}$ All these species mentioned belong to the family Arecaceae.

The best antioxidant performance of the leaves of $M$. armata $\left(\mathrm{EC}_{50}\right.$ of $50.6 \mu \mathrm{g} / \mathrm{mL})$ may be due to the amount of flavonoids $(7.92 \mathrm{mg} / \mathrm{g}$.E) that was higher than that found in $M$. flexuosa $(4.85 \mathrm{mg} / \mathrm{g} . \mathrm{E})$, in addition M. armata possesses only three compounds while $M$. flexuosa has eight (Table 4), this smaller amount of constituents in its extract reduces the possibility of interaction between the metabolites and potentiates the antioxidant activity of the extract. ${ }^{34}$

The roots of $M$. armata and M. flexuosa had intermediate values of antioxidant activity when compared to the other analyzed structures, with $\mathrm{EC}_{50}$ of 75.6 and $98.7 \mu \mathrm{g} / \mathrm{mL}$ respectively and although they presented antioxidant activity, the values are lower than that described for roots of Borassus flabellifer $(15.75 \mu \mathrm{g} / \mathrm{mL})$ that also belongs to the Arecaceae family. ${ }^{35}$ The roots of the two species presented contents of flavonoids higher than those found in petioles, as can be observed in Table 4.

It was not possible to realize the tests of antioxidant activity of the wine at any of the concentrations. Initially, the samples were cloudy, not being possible the spectrophotometric analysis. Faced with this concentrations were reduced and it was centrifuged at $14,000 \mathrm{rpm}$ and it was made white with the same centrifuged dilutions of the sample, however the absorbance was still higher than that of the control. The solvent methanol was changed to ethanol, but anyway there was no success.

The two species have phyto-constituents of interest, mainly flavonoids. It is important to perform analyzes to verify biological activities for both species, especially with $M$. armata, once the tests showed that the species has flavonoids and antioxidant activity higher than $M$. flexuosa and also because there are few studies of this plant related to the chemistry composition, besides, the prospection of these species and the proof of potential for use, can contribute to the valorization and conservation of the biome cerrado.

\section{CONCLUSION}

The presence of flavonoids allows the results of the antioxidant activity found for both species. The M. flexuosa wine evidenced secondary metabolites reported in other plant structures. Further studies should be performed to identify the active compounds.

Table 3: Chromatographic profile M. armata and M. flexuosa.

\begin{tabular}{|c|c|c|c|c|c|c|c|c|c|c|c|c|}
\hline \multicolumn{13}{|c|}{ Chromatographic profile results } \\
\hline \multicolumn{2}{|c|}{ Time (mim) } & $\begin{array}{c}4,231- \\
4,227\end{array}$ & $\begin{array}{c}4,762- \\
4,780\end{array}$ & $\begin{array}{c}5,257- \\
5,351\end{array}$ & $\begin{array}{c}5,928- \\
6,098\end{array}$ & $\begin{array}{c}6,545- \\
6,574\end{array}$ & 6,967 & $\begin{array}{c}8,500- \\
8,891\end{array}$ & 11,172 & $\begin{array}{c}12,278- \\
12,373\end{array}$ & $\begin{array}{c}13,218- \\
13,331\end{array}$ & 16,191 \\
\hline \multirow[t]{2}{*}{ Leafs } & $M a$ & M3 & & M2 & & M1 & & & & & & \\
\hline & $M f$ & M3 & $\mathrm{X}$ & M2 & $\mathrm{X}$ & M1 & & & $\mathrm{X}$ & $\mathrm{X}$ & $\mathrm{X}$ & \\
\hline \multirow[t]{2}{*}{ Root } & $M a$ & M2 & & M3 & $\mathrm{X}$ & M1 & & $\mathrm{X}$ & & $\mathrm{X}$ & $\mathrm{X}$ & \\
\hline & $M f$ & $\mathrm{X}$ & & M2 & & M1 & & M3 & & $\mathrm{X}$ & $\mathrm{X}$ & \\
\hline \multirow[t]{2}{*}{ Petiole } & $M a$ & M3 & $\mathrm{X}$ & M2 & M3 & M1 & & $\mathrm{X}$ & & $\mathrm{X}$ & $\mathrm{X}$ & $\mathrm{X}$ \\
\hline & $M f$ & $\mathrm{X}$ & & M2 & $\mathrm{X}$ & M1 & $\mathrm{X}$ & $\mathrm{X}$ & & $\mathrm{X}$ & $\mathrm{X}$ & \\
\hline \multicolumn{2}{|c|}{ Time (mim) } & 4,495 & 5,149 & 5,592 & 6,330 & 7,493 & 14,052 & & & & & \\
\hline \multicolumn{2}{|c|}{ Wine (Mf) } & M1 & M2 & $\mathrm{X}$ & $\mathrm{X}$ & M3 & $\mathrm{X}$ & & & & & \\
\hline
\end{tabular}

$M a=$ M.armata $M f=M$. flexuosa $\mathrm{X}$ - present; $\mathrm{M} 1$ = first major; $\mathrm{M} 2$ = second major; $\mathrm{M} 3$ = third major. 
Table 4: $\mathrm{EC}_{50}$, quantification of flavonoids ( $\mathrm{mg}$ of rutin/g of extract) and line equations and correlation coefficients $\left(R^{2}\right)$ of standard curves of the samples.

\begin{tabular}{|c|c|c|c|c|}
\hline Sample & Structure & $\mathrm{EC}_{50} \mu \mathrm{g} / \mathrm{mL}$ & $\begin{array}{l}\text { Flavonoids } \\
\text { (mg/g.E) }\end{array}$ & $\begin{array}{l}\text { Equation of the } \\
\text { line }\left(R^{2}\right)\end{array}$ \\
\hline \multirow{3}{*}{ M.flexuosa } & Root & 98,7 & 3,83 & $\begin{array}{c}\mathrm{y}=0,495 \mathrm{X}+1,12 \\
(0,999)\end{array}$ \\
\hline & Petiole & 309,8 & 0,5947 & $\begin{array}{c}\mathrm{y}=0,0693 \mathrm{X}+28,53 \\
(0,994)\end{array}$ \\
\hline & Leaf & 94,4 & 4,85 & $\begin{array}{c}y=0,506 x+2,24 \\
(0,997)\end{array}$ \\
\hline \multirow{3}{*}{ M. armata } & Root & 75,6 & 5,93 & $\begin{array}{c}\mathrm{y}=0,5665 \mathrm{X}+7,15 \\
(0,999)\end{array}$ \\
\hline & Petiole & 245,2 & 0,9286 & $\begin{array}{c}\mathrm{y}=0,0547 \mathrm{X}+36,59 \\
(0,9986)\end{array}$ \\
\hline & Leaf & 50,6 & 7,92 & $\begin{array}{c}\mathrm{y}=0,3995 \mathrm{X}+28,8 \\
(0,9996)\end{array}$ \\
\hline Gallic acid & - & 1,34 & - & - \\
\hline Rutin & - & - & - & $\begin{array}{c}y=0,0135 X-0,0219 \\
(0,9978)\end{array}$ \\
\hline
\end{tabular}

\section{ACKNOWLEDGEMENT}

Postgraduate Program in Biotechnology (PPGB/UNIMONTES); Minas Gerais Research Support Foundation FAPEMIG (Grant APQ-00468-1) and Brazilian National Council for Scientific and Technological Development CNPQ.

\section{CONFLICT OF INTEREST}

The Authors declare no conflict of interest.

\section{ABBREVIATIONS}

AbsAmos: Represents the absorbance value of the sample; AbsCont: Absorbance value of the control; \% AA: Antioxidant activity; $\mathbf{A l C l}_{3}$ : Aluminum chloride; DPPH: 2,2-Diphenyl1-1-Pricril-hydrazyl; $\mathbf{E C}_{50}$ : Half maximal effective concentration; HPLC: High efficiency liquid chromatography; TLC: Thin layer chromatography.

\section{REFERENCES}

1. Lorenzi H, Souza HM, Cerqueira LSC, Medeiros-Costa JT, Ferreira EE. Palmeiras brasileiras e exóticas cultivadas. Ed. Plantarum: Nova Odessa. 2004.

2. Ribeiro JF, Felfili JM, Walter BMT, Mendonça RC, Filgueiras TS, Silva MR. Caracterização florística e potencial de uso das espécies vasculares ocorrentes nas Fazendas Trijunção, BA. Embrapa Cerrados: Planaltina. 2001.

3. Freire JAP, Barros KBNT, Lima LKF, Martins JM, Araújo YDC, Oliveira GL, et al. Phytochemistry profile, nutritional properties and pharmacological activities of Mauritia flexuosa. J Food Sci. 2016;81(11):2611-22.

4. Dias JE, Laureano LC. Farmacopéia popular do cerrado. Articulação Pacari: Góias. 2010.

5. Almeida SP, Proença CEB, Sano SM, Ribeiro JF. Cerrado: espécies vegetais úteis. Embrapa Cerrados: Planaltina. 1998.

6. Lorenzi H, Noblick LR, Kahn F, Ferreira E. Flora Brasileira: Arecaceae (Palmeiras). Plantarum: Nova Odessa. 2010.

7. Cymerys M, Fernandes NMP, Rigamonte-Azevedo NOC. Buriti (Mauritia flexuosa L. f.). In: SHANLEY P, MEDINA G (Eds) Fruit and Useful Plants in Amazonian Life. Centro Internacional de Pesquisa Florestal-CIFOR: Belém. 2005; $175-82$.

8. Silva RL, Martins V, Bantim IFC, Deus MSM, Ferreira PMP, Peron AP. Flavonóides: constituição química, ações medicinais e potencial tóxico. Acta Toxic Argen. 2015;23(1):36-43

9. Saxena M, Saxena J, Nema R, Singh D, Gupta A. Phytochemistry of medicinal plants. Journal of Pharmacognosy and Phytochemistry. 2013;1(6):168-82.
10. López-Alarcón C, Denicola A. Evaluating the antioxidant capacity of natural products: A review on chemical and cellular-based assays. Anal Chim Acta. 2013;763:1-10

11. LiY, Zhang JJ, Xu DP, Zhou T, Zhou Y, Li S, et al. Bioactivities and health benefits of wild fruits. Int J Mol Sci. 2016;17(8):1258.

12. Matos FJA. Introdução à Fitoquímica Experimental. Fortaleza: Edições UFC 1997.

13. Royo VA, Araújo BCP, Barros BP. Métodos Fitoquímicos para a identificação de metabólitos secundários. Ed Novas Edições Acadêmicas. 2015.

14. Mello JCP, Cortez DAG, Cardoso MLC. Análise fitoquímica preliminar. Maringá: Universidade Federal de Maringá. 1997;12-9.

15. Falkberg $M B$, Santos $R I$, Simões $C M A$. Introdução à análise fitoquímica. $E d$. Simões CMA, Schenkel EP, Gosmann G, Mello JCP, Mentz AL, Petrovick PR Farmacognosia: da planta ao medicamento. Editora da UFRGS / Editora da UFSC, Porto Alegre. 2003;229-46.

16. Andrade RP. Ensino da função orgânica álcool por meio de experimentação numa abordagem Ciência, Tecnologia e Sociedade (CTS). Dissertação (Mestrado em Ensino de Ciências e Tecnologia). Universidade Tecnológica Federal do Paraná, Ponta Grossa. 2012

17. Cruz R, Galhardo FE. Experimentos de química em microescala, com materiais de baixo custo e do cotidiano. Editora Livraria da Fisica. 2009.

18. Beserra FP, Aguiar RWS, Carvalho EEN, Borges JCM, Vale BN. Jatropha curcas L. (Euphorbiáceae) como novo bioinseticida: análise fitoquímica preliminar atividade larvicida contra Aedes aegypti (Diptera: culicidae). Amazônia: Science and Health. 2014;2(3):17-25

19. Mercadante-Simoes MO, Mazzottini-Dos-Santos HC, Nery LA, Ferreira PR Ribeiro LM, Royo VA, et al. Structure, histochemistry and phytochemical profile of the bark of the sobol and aerial stem of Tonteleamicrantha (CelastraceaeHippocrateoideae). An Acad Bras Cienc. 2014;86(3):1167-9.

20. Alves E, Kubota EH. Conteúdo de fenólicos, flavonoides totais e atividade antioxidante de amostras de própolis comerciais. Rev Ciênc Farm Básica Apl. 2013;34(1):37-41.

21. Brand-Williams W, Cuvelier ME, Berset C. Use of a free radical method to evaluate antioxidant activity. LWT - Food Sci Technol. 1995;28(1):25-30.

22. Rufino MSM, Alves RE, Brito ES, Morais SM, Sampaio CG, Jimenez JP, et al Determinação da atividade antioxidante total em frutas pela captura do radical livre DPPH. Comunicado Técnico Embrapa. 2007;127:1-4

23. Oliveira AITD, Mahmoud TS, Nascimento GNLD, Silva JFMD, Pimenta RS, Morais PBD. Chemical composition and antimicrobial potential of palm leaf extracts from Babaçu (Attaleaspeciosa), Buriti (Mauritia flexuosa) and Macaúba (Acrocomiaaculeata). The Scientific World Journal. 2016;973-4181.

24. Bataglion GA, Silva FM, Eberlin MN, Koolen HH. Simultaneous quantification of phenolic compounds in buriti fruit (Mauritia flexuosa Lf) by ultra-high performance liquid chromatography coupled to tandem mass spectrometry. Food Res Int. 2014;66:396-400.

25. Koolen HH, Soares ER, Silva F, Souza AQ, Rodrigues Filho E, Souza AD. Triterpenes and flavonoids from the roots of Mauritia flexuosa. Rev Bras Farmacogn. 2012;22(1):189-92.

26. Koolen HH, Soares ER, Silva FM, Oliveira AA, Souza AQ, Medeiros LS, et al. Mauritic acid: a new dammarane triterpene from the roots of Mauritia flexuosa Lf (Arecaceae). Nat Prod Res 2013;27(22):2118-25.

27. Pazinato MS, Braibante HT, Braibante ME, Trevisan MC, Silva GS. Uma abordagem diferenciada para o ensino de funções orgânicas através da temática medicamentos. Quím Nova Escol. 2012;34(1):21-5.

28. Azevêdo LCD, Reis MM, Silva LAD, Andrade JBD. Effects of carbonylic compound presence and concentration on wine quality. Quím Nova. 2007;30(8):1968-75.

29. Rizzon LA, Zanuz MC, Miele A. Evolução da acidez durante a vinificação de uvas tintas de três regiões vitícolas do rio grande do sul. Ciênc Tecnol Aliment. 1998;18(2):179-83

30. Shil A, Himel MK, Khair A, Alam MN, Uddin AJ. In vitro antioxidant activity of the methanolic extracts of leaf and fruit of Calamusrotang Linn. J Expt Biosci. 2012;3:33-6

31. Rethy P, Singh B, Kagyung R, Gajurel PR. Ethnobotanical studies of dehangdebang biosphere reserve of arunachal pradesh with special reference to memba tribe. Indian J Trad Know. 2010;9(3):496-501

32. Eddine LS, Segni L, Noureddine G, Redha OM, Sonia M. Scavenging effect, anti-inflammatory and diabetes related enzyme inhibition properties of leaves extract from selected varieties of Phoenix dactylifera L. Int J Pharmacog Phytoc Res. 2014;6(1):66-73.

33. Al-Daihan S, Bhat RS. Antibacterial activities of extracts of leaf, fruit, seed and bark of Phoenix dactylifera. Afr J Biotechnol. 2012;11(42):10021-5.

34. Hidalgo M, Sánchez-Moreno C, de Pascual-Teresa S. Flavonoid-flavonoid inter action and its effect on their antioxidant activity. Food Chem. 2010;121(3):691-6

35. Uddin N, Islam R, Hasan N, Hossain MS, Roy A, Hossain MM, et al. DPPH scavenging assay of eighty four Bangladeshi Medicinal Plants. IOSR-JPBS. 2011;6(5):66-73. 


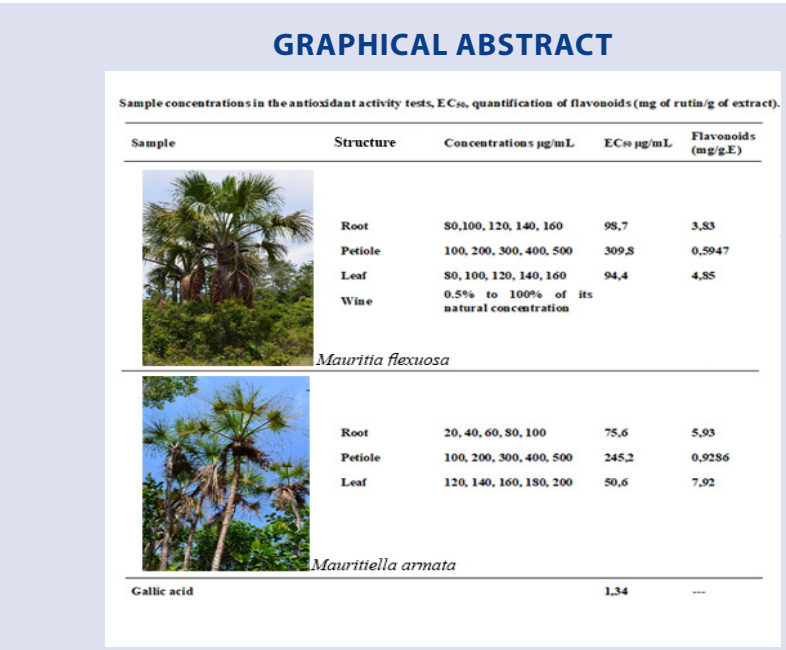

\section{SUMMARY}

- The current work were evaluated: the phytochemical profile of the $M$. flexuosa wine, antioxidant activity of leaf, root and petiole hydroethanolic extracts of the two species, as well as the quantification of flavonoids and the chromatographic profile by means of high performance liquid chromatography.

- Researchers have been stated the presence of flavonoids and antioxidant activity of were observed in the extracts of all the analyzed structures of the two species.

- Researchers have been stated the presence of phytoconstituents in wine.

- In the chromatographic analysis, it was observed that the extracts evaluated have between three and nine compounds.

\section{ABOUT AUTHORS}

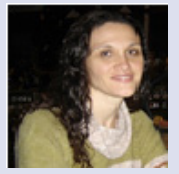

Vanessa de Andrade Royo: Professor of the Postgraduate Program in Biotechnology of the Department of General Biology, State University of Montes Claros, BRAZIL

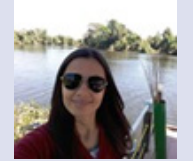

Juliana Almeida Rocha: Master's degree from the Graduate Program in Biotechnology of the Department of General Biology, State University of Montes Claros, BRAZIL

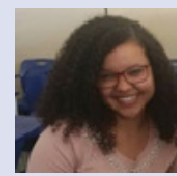

Kamylla Teixeira Santos: Student of the Graduate Program in Biotechnology of the Department of General Biology, State University of Montes Claros, BRAZIL

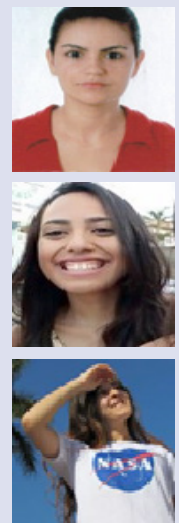

Jeane Ferreira Leal Freitas: Master's degree from the Graduate Program in Biotechnology of the Department of General Biology, State University of Montes Claros, BRAZIL

Clarice Avelar Almeida: Student of the Biological Sciences Graduation Course of the Department of General Biology, State University of Montes Claros, BRAZIL

Bianca Ribeiro: Student of the Biological Sciences Graduation Course of the Department of General Biology, State University of Montes Claros, BRAZIL

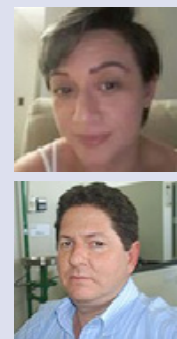

Elytania Veiga Menezes: Professor of the Postgraduate Program in Biotechnology of the Department of General Biology, State University of Montes Claros, BRAZIL

Dario Alves de Oliveira: Professor of the Postgraduate Program in Biotechnology of the Department of General Biology, State University of Montes Claros, BRAZIL

Murilo Malveira Brandão: Professor of the Postgraduate Program in Biotechnology of the Department of General Biology, State University of Montes Claros, BRAZIL

Afrânio Farias de Melo Júnior: Professor of the Postgraduate Program in Biotechnology of the Department of General Biology, State University of Montes Claros, BRAZIL

Cite this article: Royo VA, Rocha JA, Santos KT, Freitas JFL, Almeida CA, Ribeiro B, et al. Comparative Studies Between Mauritia flexuosa and Mauritiella armata. Pharmacog J. 2019;11(1):32-6. 